\title{
Impact of the different control styles (Externally directed and Self- directed) in interactive eBooks design on students' cognitive achievement and attitude towards it
}

\author{
Dr. Nader S. Shemy \\ Faculty of Education, Fayoum University, Egypt \\ Arab Open University, AOU, Oman Branch \\ nshemy@hotmail.com
}

\begin{abstract}
:
The present study aims to measure of the difference between the use of the teacher-directed control style and the total control style through self-learning by students in the use of interactive eBooks. It also aims to design a tool in the form of an interactive eBook applicable by students either in the form of self-learning or teacher-directed learning to identify the impact of the used tool. The semiexperimental approach has been used to conduct this study. The study group consisted of 24 students from the 11th grade for the academic year 2016/ 2017, second semester, in one of the public schools in Muscat Governorate. The sample consisted of 12 students in the first experimental group "total control through selflearning" and 12 students in the second experimental group "teacher-directed control." The researcher used the following tools: interactive e-book, achievement test, and measurement of attitude towards interactive e-books.
\end{abstract}

The results of the study showed the following:

1. There were statistically significant differences at $(0.05)$ between the mean scores of the two experimental groups between the pre and post measurement of the achievement test in favor of the post-test.

2. There were no statistically significant differences between the post-test of the two experimental groups including overall control and directed control in favor of directed control.

3. There were statistically significant differences between the mean scores of the two experimental groups, total control and directed control, in favor of directed control in the attitude towards interactive e-books. 


\section{Keywords:}

Control styles, self-learning, interactive eBooks, cognitive achievement, teacher-directed control, total self-control.

\section{Introduction}

Interactive eBooks are one of the most important sources of e-learning that have helped both educational designers and teachers to overcome the shortcomings that we find in the paper books, because interactive eBooks are dynamic and interactive. In addition to possessing the characteristics of paper books, they are characterized by new features and characteristics that create an interactive environment that is suitable for many types of learning styles.

Interactive eBooks have many forms in their final version according to the authoring programs used in their preparation, which are competing in the production of these books with their additions, especially with regard to the interactive side and their pages' control, so it was important to organize these books to enable the learner to browse and store. This is done by linking the elements of the appropriate educational design to the educational theory used. So the produced interactive eBooks will serve the educational purposes in a specific and clear way that enables the learner to interact with the e-book and achieve active learning (Ibrahim, 2011).

Directed control style is considered one of the most important elements in the design of e-learning in general and in interactive eBook design in particular. Control means that the user knows what he is using, how to search, where he is now, and what options he has (Rose, 2011).

Morineau (2005) and Rose (2011) point out that one of the main problems that face users of interactive eBooks is the lack of control and directing styles while browsing, and the inability to determine the electronic content environment and the characteristics and level of learners.

Patricia (2005) emphasizes the importance of control and directing tools in eBooks to help users navigate through the pages of the book in terms of forwardness and backwardness or starting. The tools of electronic book control range from links, lists, cognitive maps, indexes, content tables, image collections, timelines, research words, visual simulations, guidance tours, search engines, etc. 
Yoon (2005) believes that it is difficult to use the linear control style in interactive eBooks, so it is necessary to use the non-linear control style in the environment of the interactive books by using two tools, namely, cognitive maps and frame menus, because they help the user navigate the interactive eBook freely, and consequently contribute to the achievement of different learning outcomes.

In the same context, academic achievement is considered one of the most important learning outcomes that reflect the real image of the effectiveness of interactive eBooks. Therefore, it is necessary to improve the learning process using these interactive books and to measure their effectiveness in students' academic achievement compared to using the traditional style of paper books (Flashman, 2012).

Khamis (2010) believes that there is a significant relationship between the use of directed control style in interactive e-books and the level of academic achievement. Because the lack of guidance and direction in the interactive eBooks environment negatively affects the interconnection between the content parts, thus affecting the assimilation and collection of content-related experiences by students. In contrast, the use of the control style makes the instruction process clearer and consequently improves understanding and achievement, and the user also feels satisfied and able to learn.

Total control style through self-learning is one of the methods used to employ technology in education. This technology is used to design high-capacity programs in the process of individualization of education, which have paid off due to their attention to individual differences between learners, as well as their importance in meeting the needs of individuals taking into account their characteristics and advantages, and consequently their positive impact is reflected on students' academic achievement (Hadi, 2004).

Self-learning, as defined by Muhammad (2007), is an activity that an individual does as a result of self-motivation, In order to develop his abilities, aptitudes, tendencies and attitudes in learning. He added that self-learning has features that distinguish it from other styles of learning, such as the diversity and multiplicity of educational aids, the ability to rely on oneself, and encouraging creativity and innovation. 
The importance of talking about the impact of total control style through selflearning in interactive e-books, that is based on the cognitive and the behavioral theory on academic achievement lies in the characteristics of these eBooks, and in the self-learning needs imposed themselves on the educational designers. Among the characteristics of those books are being consistent with the needs of selflearning, the ability to control and manage by users themselves, the ability to interact with the elements of the eBook including educational content and more, the availability of support element, containing multimedia, availability of instant feedback, and the possibility of using it at any time. It also provides the element of excitement and suspense, flexibility in use and other characteristics that, once available in any interactive eBook serving self-learning, it will raise the motivation of the learner towards academic achievement.

Briefly, in this research we will discuss the impact of the difference in the style of control of interactive e-books on the cognitive achievement and the attitude of basic education students in the Sultanate of Oman, addressing the total control style through self-learning and teacher-directed control style, e-books, and cognitive achievement. We will also link all the variables through previous studies. We will also implement an electronic program based on cognitive and behavior theory as a model for interactive eBooks to investigate the impact of research variables on cognitive achievement.

\section{Sensation of the problem}

The researcher's sense of the problem came through what he noticed during the observation of the teaching process in many schools. He has observed the students' reluctance to use electronically available interactive e-books, their attitude towards them, and their inability to understand all of their contents and control of their use as a kind of self-learning through the computers available in schools or through their availability on the Internet which is a key source for the study of the scientific material required to be learned by the students, despite of knowing these eBooks and how to use them, the thing that had a profound impact on the low level of students' knowledge.

Sensation of the problem also came from the results of previous studies which indicate the importance of the teacher-directed control style in the use of interactive 
e-books without the need for self-learning by the student. This was confirmed by the results of Patricia \& Michael (2005) study, which points to the importance of using the guiding style by the teacher in the use of interactive e-books, especially in science, because it includes a variety of concepts, skills, information and experiences. Students therefore lack orientation towards use and lose attitude towards what is required to be understood from the material, thus affecting the interconnection of the content, which in turn affects the assimilation and collecting experiences related to the content, especially with pre-university students.

\section{Problem Statement}

The problem of research lies mainly in the weakness of students' use of interactive eBooks in the basic education schools in the Sultanate of Oman.

\section{Questions and Hypotheses of the Study}

To find a solution to the problem of research, the researcher seeks to answer the following main question:

What is the impact of the difference in the control style of interactive eBooks on basic education students' cognitive achievement and attitudes towards them in the Sultanate of Oman?

\section{Study Hypotheses:}

1) There are statistically significant differences at (0.05) between the mean scores of the two experimental groups between the prior and post measurement of the cognitive acquisition test in favor of the post-test.

2) There are statistically significant differences at (0.05) between the mean scores of the two experimental groups in the post-measurement of the cognitive achievement test between the teacher-directed group and the total control group through self-learning in favor of the teacher-directed control group.

3) There are no statistically significant differences at (0.05) indicating the attitude and satisfaction of students towards the use of interactive e-books in both groups. 


\section{Objectives of the Study}

The study aims to compare between the use of the teacher-directed control style and the total control style through self-learning by students in the use of interactive e-books. It also aims to design a tool in the form of an interactive eBook that can be applied by the students either in the form of self-learning or directed by the teacher to find out the effect of the used tool and compare the application impacts of directed and self-control styles on the academic achievement and the students' attitude towards eBooks.

\section{Significance of the Study}

- The importance of the study is that its results may contribute to enhancing the use of interactive eBooks in the basic education schools in the Sultanate of Oman for their importance in stirring motivation towards learning as they contain means of interaction through the method of browsing and they also include multimedia, and thus contribute to raising the level of students' achievement.

- The results of the study may also help teachers choose the best applications of interactive e-books that the student can control their scientific content.

- The results of this study may also benefit the designers and developers of interactive e-books with a set of principles when designing these books. These principles are related to the tools of control and guidance to use in order to raise the level of achievement of the student and the attitude towards their use.

\section{Research Terms}

\section{Self-learning:}

Self-learning is defined as an approach in which a person practices the educational situation by himself in order to explore information, skills and attitudes, where the center of attention in the educational process is transferred from teachers to learners.

(Amer, 2005)

Al-kindi (2010) defines it as the approach in which the learner depends on his own effort according to his own pace and abilities, using technological methods to achieve the best levels of advancement, development, and achieving goals. 
Khamis (2013) also defines it as the education based on the learner's independent choice of proper education according his own pace and abilities.

Procedurally, self-learning is defined as a set of procedures, processes, and mental practices that is possessed by the learner and helps him in self-learning, and which are considered the basis of self-learning so that the learner may not learn without them, such as readiness to learn, self-assessment, and skills of opinion sharing.

\section{Interactive eBooks:}

An eBook is a digital representation of printed texts, which can be read on electronic devices such as computers, tablets or mobile devices. (metwally, 2012).

Bozkurt \& Bozkaya (2015) define an eBook as a textbook that is converted to a digital form or digital reading materials, in the form of a file on a computer. The file consists of words and images displayed on the screen, designed to more than just reading, as it's viewable and readable at the same time.

Procedurally, interactive an eBook is defined as the container that is transferred from the printed form into the digital form. It can be read on a computer or any other digital device such as mobile phones and tablets. It's circulated on the Internet and characterized by links and tools of direction and navigation.

\section{Directed Learning:}

Directed learning is defined as an education represented in the teacher's rule in guiding students to link new ideas and concepts with their cognitive stock. It is also based on advance planning by the teacher to ensure his students learn by participating in their cognitive acquisition and guiding them to achieve a certain goal.(al-saifi, 2009)

Directed learning is procedurally defined as the process by which a teacher makes the student acquire knowledge and skills through predetermined goals, so that the teacher takes the role of teaching and the student takes the role of learning.

\section{Limitations of the Study}

The limitations of the present study are as follows:

- Time limitations: second semester of academic year 2016/2017 
- Place limitations: a public school in the Governorate of Muscat, Sultanate of Oman

- Human limitations: $11^{\text {th }}$ grade students

\section{Theoretical Framework and Previous Studies}

\section{First Axis: teacher-directed control}

In the midst of technological development and the spread of e-learning in the educational and instructional circles, it comes to mind that the teacher will have no role in education. But, on the contrary, e-learning promotes the role of teacher, because the teacher is responsible for the educational process, and he manages the plans, the educational process, and the path that the learner takes on his learning journey.

\section{The teacher's role in directed control:}

The role of the teacher is not limited to transferring knowledge and information to students, as the teacher has become director of students' activities towards achieving goals. Literature has dealt with the roles of the teacher from several aspects. Al-Ghamdi, (2013) emphasized that the role of the teacher lies in integrating technology into education, adapting to new circumstances and variations, taking into account the educational environment of students, focusing on training strategies, and equipping the learner with the skills of self-learning and research.

The teacher should be aware of the previous experiences of his students and should observe the needs of each student and provide each student with the appropriate support according their abilities. The teacher should also continuously take notes and make sure that they interact in the learning process.

Al-shehri (2015) defined about teacher's role in seven basic tasks, some of which are common with Al-Ghamdi. Al-shehri defined the guiding role of the teacher in the educational process as follows:

- Facilitating the educational process: the teacher simplifies knowledge and information, and rephrases them in a way consistent with abilities of his students whom he is well-versed of their levels. 
- Simplifying content: the teacher has a cognitive role in providing learners with skills, knowledge, facts and concepts in a simplified manner.

- The teacher is a researcher: the role of the teacher is not limited to giving information contained in the curriculum the way they are, he has become a researcher who seeks knowledge and all what's new in the time of cognitive explosion.

- Technologist: due to rapid technical and technological development, it became a must that the teacher be aware of the technologies that serve teaching and educational process, so that he can benefit from technological developments in saving effort and time.

-Experiences designer: the teacher designs experiences and student activities, whether individually or in cooperative groups in order to exchange Experiences.

- Director of the educational process: in traditional learning, the teacher's rule was limited to discipline and management of class, but in e-learning, the teacher has become a director of the entire educational process, as he decides what students should learn, the way they learn, the strategy in use, and virtually or in an integrated for, etc..

- Advice and guidance: in directed learning, the teacher plays the role of an advisor to students in everything related to their educational course. He gives advice and consultation to every student according his abilities and level.

The researcher believes that the teacher-directed control is the most important element in the success of the educational process. If the teacher realizes his role well, it seeks to put the teacher at the center of the educational process, urges him to use a learning path designed according to his knowledge of the learner's abilities and capabilities. Nevertheless, if he is not aware of his role in the educational process, he will limit his role to the role of a traditional teacher which is limited to instruction, which makes the learner just a recipient of information.

\section{Second Axis: Total Control through Self-Learning}

The concept of learning has changed from its traditional form in which the teacher is the focus of the educational process to the modern form in which the learner is the focus of the educational process, so that learning is based on 
developing the interests of the learners and takes into account the individual differences between them. Thus, the student became able to learn according to his own abilities, needs, and interests. On this basis emerged the self-learning concept which is based on giving the learner the largest role in the educational process, and making him in charge of his choices and achieving goals.

The concept of self-learning was inspired by Hoyol in 1961. Hoyol stated that learners have the motivation to participate in learning activities and achieve educational goals which bring them social and self-satisfaction. (Al-otabibi, 2015).

Self-learning has numerous characteristics that can be summarized in a number of characteristics, the most important of which are:

- Takes into account the individual differences: self-learning presents a solution for the problem of individual differences between students, as it permits every learner to learn according to the appropriate path and achieve desired goals, and gives the learner an opportunity to learn inside the small or large groups according his own pace and ability to accomplish tasks.

- Learner's positivity and interaction: the learner in self-learning is a positive participant in the educational situation. Several studies have indicated that learning based on work and activity is the best of learning kinds.

- Self-directed learner: which means that the learner is free to learn, pursue the fields he chooses according to his own attitudes in order to achieve goals; thus develops the ability to be creative and motivated to learn.

- Learner's self-evaluation: helps the learner to direct and evaluate himself, as he doesn't move from a unit to another until he masters the unit allocated he studies. (Al-kindi. 2010)

\section{Self-learning skills:}

Many literature and references emphasized that it is necessary for the learner to possess the self-learning skills that enable him to effectively undertake his roles and facilitate his future work. These fundamental skills include learning selfeducational strategy which helps him in building knowledge, in addition to helping in determining learning objectives, as the learner make any achievement unless such objectives are determined and he knows how to set goals and achieve them. 
As stated by Al-Maghraby, (2007) the most important self-learning skills to be possessed by the learner are independent thinking, absolute freedom or getting rid of the teacher's control and curriculum restrictions. However, in my opinion, this concept is over-exaggerated, and I agree with Sahloul (2015) who emphasized that the learner must control his learning, accept responsibility, be able to plan, and be independent in work. He also emphasized the importance of being cooperative in work, and agrees with Al-Kindi (2010) in the necessity of the learner's awareness of social skills that regulate his relationship with other people and his surrounding environment, and showing respect to the opinion of others.

The researcher believes that self-learning is the most important skill that should to be possessed by every student in the time of this cognitive acceleration information quantum, researcher tend to establish self-learning skill for students at the early stages of education. The researcher tends to establish the learner's skills of self-learning at the early stages of education, and encourage and direct the administrations of educational institutions to promote and adopt the concept of self-learning with teachers through training workshops to equip them with the skills of self-learning in order to be qualified enough to help their students acquire these skills according to authentic theoretical and educational basis.

\section{Third Axis: interactive eBooks}

An interactive e-book is an e-learning resource that has overcome many of the challenges, difficulties and limitations of paper books. E-Books are interactive and dynamic, with an enriching interactive multimedia learning environment.

The e-book is described in the Encyclopedia of Library and Information Science as a text similar to the book in its shape but is available in a digital format; it is displayed on the computer screen. (Mohammed, 2015)

Components of an e-book: an e-book consists of two main components, devices which are sometimes called (reader) whether they are desktop computers or laptops, and the operational software, which is responsible for displaying the book on screen, which supports various formats such as listening to eBooks. 


\section{Types used for an e-book design:}

There are three main types of eBooks format as Ebid \& Abdul Rahman (2015) pointed out:

1. E-book in PDF format: It is the most popular and most commonly used in eBooks. It's a product of Adobe International Company, easily downloaded from the Internet, works on all browsers, and does not require a special reader.

2. E-book in RTF format: This type of files can be easily edited and can be used in newspapers and magazines that can be printed in a regular and organized form.

3. E-book in HTML format: This type of files is used when the size of the book is large, requires a special reader and can be read from Internet browsers.

\section{Features and characteristics of the e-book:}

The literature mentioned many of the advantages and characteristics of the ebook in general, and in the educational process in particular. Kamel (2013) stated that the e-book takes into account the learning styles of learners through the use of various types of multimedia. The e-book contributes to addressing the differences in individual differences between learners. Each learner learns according to his ability and speed. This is confirmed by Hijazi, Azmi and Tawfiq (2011) in the design and production standards of eBooks, in the importance of taking into account cognitive methods, individual differences, and educational and technological standards in the design and production of eBooks.

Among the features of the e-book are the integration of multimedia used in the e-book to achieve efficiency and effectiveness in learning. The e-book also provides interactive activities and immediate feedback to the learner, allows different types of thorough navigation in the e-book, and has excellent links to connect parts of the content of the book to each other. In addition, it is characterized by low cost and saves spatial space. Mohammed agreed with him (2015) in that it's easy to carry and searchable, saves the cost of printing, allows you to take notes, and accessible for people with special needs.

Ebid \& Abdul Rahman (2015) noted in their study to the educational value of the e-book, saying that it contributes to transforming the role of the teacher from a 
source of information into a facilitator and a guide of knowledge and information. Thus, the learner becomes a positive learner rather than playing the role of the passive recipient of information and knowledge. The learner's achievement also increases with the motivation to participate in the educational process.

Learning is fun with the potentials provided by eBooks through the use of multimedia. The learner's independence in the educational process is developed through eBooks, as well as the ability to possess self-directed learning skills. Finally, it is easy to make edits and upgrade information and knowledge in the ebook.

The researcher believes that the activation of eBooks is an urgent necessity in our present time which is characterized by technological development, as traditional curriculums do not meet the needs and objectives of education which aims to make the learner the focus of the educational process and prepare the learner to interact and share knowledge according to his capabilities and potentials; so researchers found that the interactive e-book contributes to increasing interaction between the learner and content, and, therefore, achieve educational goals in a fun and entertaining way away from boredom and traditional form.

\section{Previous studies}

The researcher shows the efforts made by researchers in the field of study, in order to benefit from the experiences and results of these studies and support the results of the present study, and the possibility to generalize the its results. The researcher divided the studies into three main themes as follows:

\section{First Axis: Studies that dealt with teacher-directed control.}

The study of frye (2014) aimed to identify the effect of interactive eBooks on understanding, through the available interactive advantages. The study was conducted on a sample of second-grade students in a New Jersey school. The study sample consisted of 30 students who were interviewed for two years to study the impact of these interactive books on students' level of understanding. The results found that all students improved their level of comprehension, either through selflearning or through the teacher's intervention, and thus it had an impact on increasing academic achievement. 
Kamel's study (2013) aimed to find out the effect of the difference of the directing tool in the interactive eBooks on the cognitive achievement and the usability of these books to the students in the preparatory stage. The researcher used the experimental approach in her study. The study was applied to a sample of students in the preparatory stage in science at Helwan Preparatory School in Cairo. The results of the study proved the effectiveness of the teacher-directed guidance in the interactive eBooks in science on the group that used non directed self-learning in the same interactive book.

The study of Abu-Zahab and Younis (2013) also aimed to identify the effectiveness of the difference between the design styles of the interactive eBook in developing the skills of the attitudes towards it by the computer teachers. The study was applied to a sample of computer teachers in four schools in Helwan, in Egypt. The teachers were divided into four experimental groups. The observation card was used to determine the orientation towards these books. The results found that there were statistically significant differences between experimental groups before and after the application process through the notecard in favor of the post-application oriented towards the interactive e-book, and the study recommended the need to conduct studies on the effectiveness of interactive eBooks in teaching and academic achievement.

The study of Ibrahim, (2011) aimed to identify the effectiveness of open source eBooks in achieving the efficiency of education and the continuity of its impact. The study found that there are no statistically significant differences at the level (0.05) between the average score of students who learned using the teacherdirected style in the interactive eBooks in Biology and the average grades of students who followed self-learning in the subject by using the same electronic book.

The study of Abdul Aziz, (2011), aimed to identify the impact of the criteria and indicators related to the e-book on increasing the efficiency of learning among students of the education technology. The results indicated that there were no significant differences between the two experimental groups to which the teacherdirected style In the interactive eBook and self-directed style have been applied because of the standards according to which the e-book was designed and the multimedia it contains, which often replaces the guidance of the teacher. 
The study of Mutasim (2010) aimed to identify the effect of the interaction between the directed style in interactive eBooks and the self-learning style without guidance in the same e-book on academic achievement. The study found that there was no significant difference between the levels of students who studied using the control style in the interactive e-book and self-learning based on the e-book without guidance.

\section{Second Axis: Studies that dealt with total control through self-learning}

Al-Otaibi study (2015) aimed to identify the direct and indirect effects of selfdirected learning skills and learning and academic achievement methods. The researcher used the causal relationship modeling approach, where he applied the study on a random sample of 140 students from the Community College at King Saud University. The results showed that self-learning skills were moderate in direct impact, while the indirect impact on self-directed learning skills was multiplied several times. The researcher found out that self-directed learning skills are important in that they play the role of a mediator between learning methods and academic achievement.

Sahlol's study (2015) also dealt with the self-directed learning skills of Zagazig University students and their readiness. The study was applied to 292 first and fourth-year students of the university, using the descriptive approach in the study procedures. The results showed that the university students possessed self-directed learning skills with a medium degree and low readiness. Therefore, the researcher recommended redesigning the learning environment and encouraging students to develop self-directed learning skills.

The study of Helat, Rizk, and Khawaja (2015) dealt with self-organized learning strategies, comparing a sample of talented and untalented students. The researchers used the descriptive approach. The study found that there are differences in self-organized learning strategies between talented and untalented students in favor of talented students in record-keeping, monitoring, planning and setting goals strategies.

\section{Third Axis: Studies which discussed Interactive eBooks.}

Alshayea and ibn shennan study, (2010) aimed to find out the impact of using eBooks on developing creative thinking and the tendency towards using computer 
on learning Biology for secondary school second-year students. The two researchers have pursued the experimental approach in their study. Results showed that there are statistically significant differences in the skill of flexibility, authenticity, and details in favor of the experimental group, and that there are no statistically significant differences between the two groups regarding the tendency towards using computers in learning Biology.

The study of Hijazi, Azmi, and Tawfiq (2011) aimed to define the most important standards for the production and design of eBooks for university students. The researchers have followed the descriptive approach in their study. The researchers emphasized the most important standards of eBook production by reference to literature and previous studies and through the views of arbitrators, they found out the final image of the list of eBook standards. In addition, they referred to the importance, benefits, and advantages of eBooks and their role in the success of the educational process at all educational stages, especially the university stage

Kamel's study, (2013) aimed to discuss the impact of different navigation and direction in eBooks on the cognitive achievements and the usability of such eBooks among students of preparatory school. The study was applied to 30 male students of the seventh-grade at Helwan School in Cairo. The researcher used the descriptive approach in her study. She found out that there is a relation between the inquiry tool, cognitive maps, the positive impact on achievement, the increased concentration of students, easy navigation in eBooks, taking a comprehensive look on their contents, and the way they are organized compared to other processing, which resulted in higher academic achievement and raised their motivation.

The study of Bozkurt \& Bozkaya, (2015) also discussed the evaluation standards of open interactive eBooks and distance learning. This study used the mixed-methods study in order to determine these standards. Quantitative and qualitative data were collected from four courses, 3 experts, and examining 20 interactive eBooks, along with using the deductive approach. Then the study came out with 37 standards for interactive eBooks. Standards were developed in a research paper in order to discuss its importance and effectiveness. 
The study of Ebid \& Abdul Rahman, (2015) aimed at discussing the impact of interactive eBook on the achievement of Najran university students in using computer during a training course. The two researchers used the semi-experimental approach on a sample of 60 Najran university students. Students were divided into a control group composed of 30 students, and experimental group of 30 students. The experimental group studied computer using the interactive eBooks, but the control group studied computer subject using printed books. The study showed that there are statistically significant differences between students in academic achievement in favor of the experimental group.

\section{Present Study Approach}

In this study, the researcher adopts the descriptive analytical approach in the theoretical framework, previous studies, along with discussing the subject in all its theoretical aspects. He uses the semi-experimental approach in applying the experiment to groups, use of achievement test and measurement of attitude towards interactive eBooks in order to identify the impact of different control styles in interactive eBooks on cognitive achievement and draw conclusions from it.

\section{Second: Study Sample}

The researcher selected a random sample of 26 students from a public school in the Sultanate of Oman. The sample was divided into two experimental groups. Each group composed of 13 students. The teacher directed control style in interactive eBooks was used with the first group. But in the second one, the selfcontrol style was used.

\section{Third: Study Variables}

The present study includes independent and dependent variables as follows:

Independent variables: interactive eBooks of both self and directed control.

Dependent variables: cognitive achievement, and the attitude towards interactive eBooks.

\section{Fourth: Tools of the Study}

The tools of the study are the following:

\section{The First Tool: Interactive eBooks.}


The researcher designed an interactive eBook based on the instructional Design model (ADDIE) through the following stages:

\section{-Analysis stage:}

1) Needs analysis: at this stage, the target group has been carefully studied in terms of the following aspects: Analyzing the characteristic, needs and educational abilities of the learners by reference to their records of cognitive achievement. It was clear from the interviews that all students have sufficient information about how to deal with computer and its extras. In addition, all students have the motivation to learn and exploring the new things.

2) Goals analysis: after completing the needs analysis and accurately identifying the problem, we moved to the analysis of the goals of the lesson by deriving them from the goals of unit and presenting them to specialized arbitrators in the subject of Biology in order to verify scientific accuracy and linguistic integrity, and properly determine the required level.

3) Content analysis: content has been analyzed and organized according to specific learning tasks.

4) Constraints analysis: all physical and human resources for the interactive eBook design have been determined. Constraints that may encounter the design, development and performance process have been also determined. Then, many solutions that would reduce the ratio of constraints encountering the interactive eBook in all its stages.

\section{-Design stage:}

Interactive eBook scenario design: at this stage, planning for all tasks and activities that will be used in eBook, has been planned on paper and in an easy way that helps students complete the learning process, and strategies for the presentation of content have been chosen.

\section{-Developing stage:}

At this stage, the outputs that have been developed on paper during the design stage are developed into productive and concrete materials that can be handled as follows:

Development of interactive eBook scenario: he spent a lot of time and effort at this stage through preparation and application of scientific content that included the following: 4 videos, 10 photos, 2 educational activities, and 14 content papers. 
Several programs have been used in producing the content and after finishing all the processes; the content was grouped in one PDF file and exported to Kotobee program, as it supports the Arabic language. After finishing the preparation of all of the aspects of the book, it was exported in a Windows compatible format, as it will be used in the school's computer laboratory.

\section{- Interactive eBook Experimental Stage:}

The eBook has been experimented on pilot sample of 10 students. After finishing the experimentation, it has been presented to Biology and Science teachers in order to explore their opinions.

\section{- Implementation Stage:}

At this stage, the interactive eBook has been applied to the research basic sample in order to measure the impact of difference in control style in interactive eBooks on academic achievement of eleventh grade students.

\section{Second Tool: Achievement/Cognitive Test}

The researcher used achievement/cognitive test prepared by the school's Biology teacher, which aimed to measure the level of cognitive achievement of students before and after using interactive eBooks using both self-directed and directed styles. The validity and reliability of the test have been measured using the conventional research methods.

\section{Third tool: Measurement of Attitude towards Interactive eBooks}

By reference to the previous studies that measure the attitude towards interactive eBooks, the researcher depended on them in the drafting of 40 paragraphs that measure the attitude towards learning using interactive eBooks. After finishing the measurement preparation and building its paragraphs, and in order to ensure face validity, the measurement was presented, in its initial form, to information technology experts in order to ensure the interrelation of all of the measurement paragraphs, clarity and proper formulation, and compatibility to achieve the goal for which the measurement was set.

\section{Fifth: Research Procedures}

\section{Calculation of Parity procedures}


Table (1)

\begin{tabular}{|c|c|c|c|c|c|c|c|c|}
\hline \multirow{3}{*}{ The group } & \multicolumn{5}{|c|}{ Parity Differences } & \multirow{3}{*}{$\begin{array}{l}\text { Value of } \\
\text { (T) }\end{array}$} & \multirow{3}{*}{$\begin{array}{l}\text { freedom } \\
\text { degree }\end{array}$} & \multirow{3}{*}{$\begin{array}{c}\text { Significan } \\
\text { t level }\end{array}$} \\
\hline & \multirow{2}{*}{$\begin{array}{l}\text { Arithmetic } \\
\text { average }\end{array}$} & \multirow{2}{*}{$\begin{array}{l}\text { Standard } \\
\text { deviation }\end{array}$} & \multirow{2}{*}{$\begin{array}{l}\text { Standard } \\
\text { error }\end{array}$} & \multicolumn{2}{|c|}{$\begin{array}{l}\text { Level of difference of } \\
\text { confidence } 95 \%\end{array}$} & & & \\
\hline & & & & lower & higher & & & \\
\hline $1 \&$ & -.00833 & 2.25044 & . & -1.43819 & 1.42153 & -.013 & 11 & .990 \\
\hline
\end{tabular}

Table (1) shows that there is a parity between both experimental groups, the group of total control through self-learning and the group of teacher-directed control, where the value of $\mathrm{T}$ is as follows:

(-.013) at significant level (.990), and the ratio of parity between the two groups is $95 \%$. This means that both groups have the same abilities, characteristics and previous cognitive outcome, which confirmed to the research team the validity of the chosen sample.

\section{Experiment Implementation:}

Interactive eBook based on teacher-directed control has been made available to students, and there were clear instructions to fully abide to the teacher's instructions while moving between the book pages and when interacting with activities and assessments included therein. These instructions were in part printed and were distributed to students with the eBook, and the other part was audible or visible and directly presented by the teacher at the same time of using the eBook. There was thorough and direct supervision by teacher all the time.

The interactive eBook based on total self-control has been made available, and all instructions and guidance were included in the eBook itself in a special link. However, they were not binding to students, as they can freely sequentially or randomly search the book, and they were permitted to carry out the activities and exercises included in interactive eBook at any time they wish. In this case, the teacher doesn't interfere with the students' use of the eBook all the time. All choices and advantages existing in the eBook were made available to students without any restrictions, conditions, or external direction. It was only self-direction based on instructions that are not binding to them. 


\section{Study Results, Discussion and Interpretation}

\section{First: Testing the Validity of the First Hypothesis}

In order to test the validity of this hypothesis, the researcher used a $\mathrm{T}$ test of the samples in order to measure and calculate the significance and differences between the average score of the pre and post cognitive achievement test of the two groups as shown in the following table:

Table (2)

The result of $T$ test of the differences between the mean score of the teacher-directed control group for the pre and post application.

\begin{tabular}{|c|c|c|c|c|c|c|c|c|}
\hline \multirow{3}{*}{$\begin{array}{c}\text { Teacher- } \\
\text { directed } \\
\text { control group }\end{array}$} & \multicolumn{5}{|c|}{ Even differences } & \multirow{3}{*}{ T value } & \multirow{3}{*}{$\begin{array}{c}\text { Degree Of } \\
\text { Freedom }\end{array}$} & \multirow{3}{*}{$\begin{array}{c}\text { ignificance } \\
\text { level }\end{array}$} \\
\hline & \multirow{2}{*}{$\begin{array}{c}\text { Arithmetic } \\
\text { average }\end{array}$} & \multirow{2}{*}{$\begin{array}{l}\text { standard } \\
\text { deviation }\end{array}$} & \multirow{2}{*}{$\begin{array}{c}\text { Standard } \\
\text { error }\end{array}$} & \multicolumn{2}{|c|}{$\begin{array}{c}\text { Confidence } \\
\text { difference level } 95 \%\end{array}$} & & & \\
\hline & & & & Less & higher & & & \\
\hline Pre/post & -2.12500 & .90767 & .26202 & -2.70171 & -1.54829 & -8.110 & 12 & .000 \\
\hline
\end{tabular}

Table (2) shows that there are statistically significant differences between the mean scores of the teacher-directed control group between the pre and post cognitive achievement. The value of $(\mathrm{T})$ is: $(-8.110)$ at the significance level $(.000)$, which is less than the significance level (0.05).

Here, we note that the result is in favor of the post-test in the teacher-directed control group.

\section{Table (3)}

The result of $T$ test of the differences between the mean scores of the total control group through self-learning of the pre and post application.

\begin{tabular}{|c|c|c|c|c|c|c|c|c|}
\hline \multirow{3}{*}{$\begin{array}{c}\text { Teacher- } \\
\text { directed control } \\
\text { group }\end{array}$} & \multicolumn{5}{|c|}{ Even differences } & \multirow{3}{*}{ T value } & \multirow{3}{*}{$\begin{array}{l}\text { Degree of } \\
\text { Freedom }\end{array}$} & \multirow{3}{*}{$\begin{array}{l}\text { significan } \\
\text { ce level }\end{array}$} \\
\hline & \multirow{2}{*}{$\begin{array}{l}\text { Arithmetic } \\
\text { average }\end{array}$} & \multirow{2}{*}{$\begin{array}{r}\text { standard } \\
\text { deviation }\end{array}$} & \multirow[t]{2}{*}{$\begin{array}{c}\text { Standard } \\
\text { error }\end{array}$} & \multicolumn{2}{|c|}{$\begin{array}{c}\text { Confidence difference } \\
\text { level } 95 \%\end{array}$} & & & \\
\hline & & & & Less & higher & & & \\
\hline Pre/post & -.67273 & 1.17396 & .35396 & -1.46140 & .11595 & -1.901 & 10 & .087 \\
\hline
\end{tabular}

International Journal of Internet Education

http://ijie.journals.ekb.eg/ 
Table (3) shows statistically significant differences between the mean scores of the total control group through self-control between the pre and post cognitive achievement, where the value of $(\mathrm{T})$ is as follows: (-1.901) at the significance level (.087), which is less than the significance level (0.05).

From the above tables (2) and (3), the result of the first hypothesis is correct. The validity of the first hypothesis proved by the existence of statistically significant differences between the pre and post-test of the two experimental groups in favor of the post test. Yami study (2014) confirms the validity of the hypothesis which showed that there were statistically significant differences between the results of the pre and post-test of the experimental and control groups in favor of the post test of the experimental group.

\section{Second: Testing the Validity of the Second Hypothesis}

In order to test the validity of this hypothesis, the researcher used a $T$ test of the samples in order to measure and calculate the significance and differences between the average score of the post cognitive achievement test of the two groups.

Table (4)

The result of $T$ test of the differences between the mean scores of the total control group and the directed-control levels of the post application

\begin{tabular}{|c|c|c|c|c|c|c|c|c|}
\hline \multirow{3}{*}{ Groups } & \multicolumn{5}{|c|}{ Even differences } & \multirow{3}{*}{ T value } & \multirow{3}{*}{$\begin{array}{l}\text { Degree of } \\
\text { Freedom }\end{array}$} & \multirow{3}{*}{$\begin{array}{l}\text { significanc } \\
\text { e level }\end{array}$} \\
\hline & \multirow{2}{*}{$\begin{array}{l}\text { Arithmetic } \\
\text { average }\end{array}$} & \multirow{2}{*}{$\begin{array}{l}\text { Standard } \\
\text { deviation }\end{array}$} & \multirow{2}{*}{$\begin{array}{c}\text { Standard } \\
\text { error }\end{array}$} & \multicolumn{2}{|c|}{$\begin{array}{c}\text { Confidence } \\
\text { difference level } 95 \%\end{array}$} & & & \\
\hline & & & & Less & higher & & & \\
\hline $\begin{array}{l}\text { Post total control/ post } \\
\text { directed control }\end{array}$ & 1.09091 & 2.01020 & .60610 & -.25956 & 2.44138 & 1.800 & 10 & .102 \\
\hline
\end{tabular}

Table (4) shows that there are no statistically significant differences between the mean scores of the total control group through self-learning and the teacherdirected control in the post-cognitive achievement test. The value of (T) is: (1.800) at significance level (.102), which is below the significance level (0.05).

In the above table (4), this hypothesis has been proven incorrect because there are statistically significant differences between the post test of the two 
experimental groups, the total control and the directed control in favor of the directed control. This result strongly indicates the effectiveness of self-learning and the responsibilities and duties of the learners towards their learning, without direct guidance from the teacher despite the wide influence of the teacher on his students in the traditional form practiced in all public schools in the Sultanate.

This result also strongly indicates the effectiveness of depending on learners to learn on their own, and at least reducing the role of the teacher in the implementation of activities and exercises, as learning outcomes will not be greatly affected by reducing the role of the teacher and giving learners extensive powers and responsibilities in learning. Based on that result, learning outcomes were equal and there was no significant difference between the two experimental groups.

\section{Third: Testing the Validity of the Third Hypothesis}

In order to test the validity of this hypothesis, the researchers used the $\mathrm{T}$ test of the samples to measure and calculate the significance and differences between the average scores of the attitude towards interactive eBooks.

Table (5)

The result of the test ( $T$ ) of the differences between the average score of the total control group and the directed control group on the measurement attitude towards interactive eBooks.

\begin{tabular}{|c|c|c|c|c|c|c|c|c|}
\hline \multirow{3}{*}{ Groups } & \multicolumn{5}{|c|}{ Even differences } & \multirow{3}{*}{ T value } & \multirow{3}{*}{$\begin{array}{c}\text { Degree } \\
\text { of } \\
\text { Freedom }\end{array}$} & \multirow{3}{*}{$\begin{array}{l}\text { significance } \\
\text { level }\end{array}$} \\
\hline & \multirow{2}{*}{$\begin{array}{l}\text { Arithmeti } \\
\text { c average }\end{array}$} & \multirow{2}{*}{$\begin{array}{l}\text { Standard } \\
\text { deviation }\end{array}$} & \multirow{2}{*}{$\begin{array}{l}\text { Standard } \\
\text { error }\end{array}$} & \multicolumn{2}{|c|}{$\begin{array}{l}\text { Confidence difference level } \\
95 \%\end{array}$} & & & \\
\hline & & & & Less & Higher & & & \\
\hline $\begin{array}{l}\text { Post total control/ } \\
\text { post directed control }\end{array}$ & .18682 & .59804 & .18032 & -.21495 & .58859 & 1.036 & 10 & .325 \\
\hline
\end{tabular}

Table (5) shows that there are no statistically significant differences between the mean scores of the total control group through self-learning and the teacherdirected control in the attitude towards interactive eBooks. The value of (T) is: (1.036) at the significance level (.325), which is below the significance level $(0.05)$.

Through the above table (5), the result of the third hypothesis is correct and accepted by the researcher, since this hypothesis proved that there are no 
statistically significant differences between the average of the two experimental groups, total and directed control in favor of directed control towards interactive eBooks. Since the previous studies confirm the validity of the hypothesis that was developed by the research team. An interactive eBook with all its advantages has a positive impact on students regardless of the type of control available to them. This emphasizes the effectiveness of these eBooks in creation targeted learning, thus students are increasingly convinced of their importance in learning.

\section{Recommendations:}

1. Design and creation of e-books that serve material with abstract content for student interaction and achieve better results in cognitive achievement.

2. Providing a teacher specialized in educational technology at schools to design and make interactive eBooks available to teachers.

3. The Importance of studying the study elements that are related to the styles of control and direction in interactive eBooks as they are not less important than the elements related to the educational content. 


\section{References:}

Ibrahim, Magda Anwar, (2011). The Effectiveness of the Open-Source Ebook in Achieving Efficient Learning and the Continuity of its Impact. Cairo: Helwan University

Abu el-Dahab, Mahmoud and Yunus, Sayed, (2013). The Effectiveness of the Difference in Some of Interactive E-book Design Styles in Developing Design Skills and the Production of E-courses by Computer Teachers. An Arabic Study in Education and Psychology, 1(41), 154-200).

Badi, Abdullah Damen, (2001). The Impact of Using Computer in Education on the Immediate and Deferred Achievement of Tenth Grade Students in Chemistry in the Governorate of Slieve. Unpublished Master thesis. Palestine: An-Najah National University.

Hijazi, Amira Samir, and Azmi, Nabil Gad, and Tawfik, Marwa (2011). Standards of the design and production e-books for university stage. Egypt Studies and Researches. 90-3.

Hassan/Mahmoud Hamada (2007). The impact of the difference in navigation style design in the multimedia computer program and the level of self-learning ability on developing the digital reference service of the students of the Library, Information, and Educational Technology Section at the Faculty of Education. A Series of Studies and Researches. 17(4) October.

Khamis, Mohamed Attiya, (2013). The Theory and Educational Research in Educational Technology. Cairo: al-Sahab for Publishing and Distribution.

Sahloul, Waleed Shawki, (2015). Self-Directed Learning skills of Zagazig University Students and the their Readiness to it. Faculty of Education Magazine. Ain Shams University.(39) . 3 . 230-290.

Al-Shayea, Fahd, and Ibn Shinan, Ali Saoud, (2010). The impact of using ebooks on developing creative thinking and the attitude towards using computers in learning Biology by students of second year, secondary school in Riyadh. Magazine of Sanaa Educational and Psychological Sciences. Yemen. (7) . 1 . 122- 139 .

Al-Shahri, Saad, (2015). The Teacher's Role in Educational Technology. Educational technology blog. 
Salah, Samir Yunus, (2006). Self-Learning and Reading. (1st edition). Publishing and Distribution House.

Al-Saifi, Atef, (2009). The Teacher and Modern Education Strategies. Oman: Osama House for Publishing and Distribution.

Otaibi, Khaled, (2015). Modeling of Causal Relationships between SelfDirected Learning Skills and Academic Achievement of Community College Students, King Saud University. Jordanian Magazine of Educational Sciences. (11) . 3 . 255- 268 .

Kamel, Dalia Ahmed Shawki, (2013). The Impact of the Difference in Navigation and Direction Tools in EBooks on Cognitive Achievement and Usability of these Books by Preparatory Stage Students. Unpublished Master Thesis. Cairo: Azhar University.

Al-Kindi, Mehana Suleiman, (2010). Self-Learning and Practice Reality in the Educational Field, Schools of the Sultanate of Oman as a Model. (First Edition) Damiry Bookstore for Publishing and Distribution. Sultanate of Oman.

Metwaly, Shirin Mohamed Mohamed, (2012). The Impact of using Conversion Styles in E-books on the Achievement of Students of Basic Education and the Development of their Attitudes towards these Books. Master Thesis. Cairo: Helwan University.

Mohamed, Sawsan, (2007). The Effectiveness of some E-book Design Variations in Self-Learning Skills, Students Impressions, and Information in Educational Technology Curriculum. PhD Thesis. Females Faculty: Ain Shams University.

Medad, (2017). Directed Learning. Retrieved on April 23, 2017 from www.midad.com

Mohamed, Emad Eisa, (2015). EBook: Concept and Characteristics. Faculty of Arts: Helwan University.

Al-Hadi, Mohamed Fathi, (2004). Electronic Publishing and Electronic Information Sources. Cairo: Scientific Culture House.

Al-Helat, Mustafa, and Rizq, Abdullah, and Al-Khawajah, ahmed. 19-21 May, 2015. Strategies of Self-Organized Learning: A Comparative Study between a sample of talented and untalented students. The Second International Conference for the Gifted and Talented Towards a National Strategy to Take Care of Innovators. University of the United Arab Emirates. 
Bozkurt .A \& Bozkaya.M.(2015). Evaluation Criteria for Interactive EBooks for open and Distance Learning. International Review of Research in Open and Distributed Learning . (16).5 .

-Ebied.M, Abdul Rahman.S.(2015). The effect of interactive e-book on students' achievement at Najran University in computer in education course . Journal of Education and Practice . (6) .19.

Flashman \& Jennifer.(2012). Academic Achievement and Its Impact on Friend Dynamics. Journal Articles; Reports - Evaluative,85(1),PP.61-80.

Frye, S. (2014). The implications of interactive eBooks on comprehension. Unpublished Doctoral Thesis, Graduate School of Education, Rutgers University, New Jersey. USA.

Morineau, T., Blanche, C., Tobin, L., \& Gueguen, N. (2005). The emergence of the contextual role of the e-book in cognitive processes through an ecological and functional analysis. International Journal of HumanComputer Studies, 62(3), 329-348.

Patricia, M. \& Michael, D. (2005). The effects of spatial layout on relationships between performance, path styles and mental representation in a hypermedia information search task, Interactive Technology \& Smart Education, 2: $31-45$.

Rose, E. (2011). The phenomenology of on-screen reading: university students' livea experience or digitised text. British Journal of Educational Technology, 42(3), 515-526.

Yuyan, Su, \& Klein, J, d. (2006). Effects of navigation tools and computer confidence on performance and attitudes in a hypermedia learning environment, Journal of educational multimedia of hypermedia, 15(1)87-106. 